\title{
Impact of the Low-Temperature Reactivity of Reillex(TM) HPQ on Actinide Processing
}

by

J. E. Laurinat

Westinghouse Savannah River Company

Savannah River Site

Aiken, South Carolina 29808

W. J. Crooks III

E. A. Kyser III

DOE Contract No. DE-AC09-96SR18500

This paper was prepared in connection with work done under the above contract number with the U.S. Department of Energy. By acceptance of this paper, the publisher and/or recipient acknowledges the U.S. Government's right to retain a nonexclusive, royalty-free license in and to any copyright covering this paper, along with the right to reproduce and to authorize others to reproduce all or part of the copyrighted paper. 
This document was prepared in conjunction with work accomplished under Contract No.

DE-AC09-96SR18500 with the U.S. Department of Energy

\section{DISCLAIMER}

This report was prepared as an account of work sponsored by an agency of the United States Government. Neither the United States Government nor any agency thereof, nor any of their employees, makes any warranty, express or implied, or assumes any legal liability or responsibility for the accuracy, completeness, or usefulness of any information, apparatus, product or process disclosed, or represents that its use would not infringe privately owned rights. Reference herein to any specific commercial product, process or service by trade name, trademark, manufacturer, or otherwise does not necessarily constitute or imply its endorsement, recommendation, or favoring by the United States Government or any agency thereof. The views and opinions of authors expressed herein do not necessarily state or reflect those of the United States Government or any agency thereof.

This report has been reproduced directly from the best available copy.

Available for sale to the public, in paper, from U.S. Department of Commerce, National Technical Information Service, 5285 Port Royal Road, Springfield, VA 22161, phone: (800) 553-6847, fax: (703) 605-6900, email: orders@ntis.fedworld.gov online ordering: http://www.ntis.gov/support/index.html

Available electronically at http://www.doe.gov/bridge

Available for processing fee to U.S. Department of Energy and its contractors, in paper, from: U.S. Department of Energy, Office of Scientific and Technical Information, P.O. Box 62, Oak Ridge, TN 37831-0062, phone: (865) 576-8401, fax: (865) 576-5728, email: reports@ adonis.osti.gov 


\title{
IMPACT OF THE LOW-TEMPERATURE REACTIVITY OF REILLEX ${ }^{\mathrm{TM}}$ HPQ ON ACTINIDE PROCESSING
}

\author{
James E. Laurinat, William J. Crooks III, and Edward A. Kyser III \\ Westinghouse Savannah River Company, Aiken, SC, 29808, USA
}

\begin{abstract}
$\underline{\text { ABSTRACT }}$
Reactive System Screening Tool ${ }^{\mathrm{TM}}$ data and a computational model are used to predict the impact of pressurization on a typical process-scale ion exchange column due to gases generated by a low temperature exothermic reaction (LTE). The LTE results from a reaction between nitric acid and the ethylbenzene pendant groups of the Reillex ${ }^{\mathrm{TM}} \mathrm{HPQ}$ resin. This reaction would occur if the resin bed were inadvertently heated above $70{ }^{\circ} \mathrm{C}$.
\end{abstract}

\section{INTRODUCTION}

Organic ion exchange resins are used to purify actinide product streams from the Plutonium URanium Extraction (PUREX) process at the Savannah River Site (SRS). Nitric acid is the solvent of choice for the product finishing processes because actinides form unique anionic nitrate complexes that participate in anion exchange. However, calculated enthalpies of reaction for organic materials and nitric acid strongly favor spontaneous reactions. Gaseous products from these resin decomposition reactions pose 
a safety risk due to pressurization of the ion exchange column. However, organic synthesis can fine-tune the chemical structure of the resins to enable kinetically slow oxidation reactions under typical operating conditions. Reillex ${ }^{\mathrm{TM}}$ HPQ anion exchange resin was developed and targeted for applications in the nuclear industry that require thermal stability to nitric and radiation exposure. (1) This resin is composed of vinylpyridine copolymer subunits, which are thermally more stable than traditional styrene-alkyl ammonium copolymer subunits.

In the preceeding article(2), Reillex ${ }^{\mathrm{TM}} \mathrm{HPQ}$ exhibited runaway reaction behavior in nitric acid above $100{ }^{\circ} \mathrm{C}$, in addition to a surprising low-temperature exotherm (LTE) that initiated at about $69{ }^{\circ} \mathrm{C}$. Based on the analysis of the reaction products, a reactivity study of model compounds, and literature precedents, the LTE was attributed to ethylbenzene pendant groups. To eliminate the LTE, a nitric acid pretreatment was developed to oxidize the ethylbenzene pendant groups selectively, and to reduce the resin's low temperature reactivity. Safety concerns with performing this pretreatment on a process scale led to an evaluation of alternate pretreatments, but none was identified. In this work, Reactive System Screening Tool (RSST) data and a computational model are used to predict the amount of pressurization of a typical process-scale ion exchange column due to inadvertent heating that activates the LTE.

\section{EXPERIMENTAL}

\section{$\underline{\text { Reagents }}$}

All chemicals used in this study were reagent grade and were used without additional purification. Eight molar nitric acid solutions were prepared from dilutions of 
stock nitric acid (69.7\%, purchased from Fisher Scientific, Inc.). Reillex ${ }^{\mathrm{TM}} \mathrm{HPQ}$ (chloride form 1998 Lot Number 80302MA) was purchased from Reilly Industries, Inc.

\section{$\underline{\text { Resin Preparations }}$}

Prior to analysis in the RSST, resins were converted from commercially available chloride form to nitrate form by washing with 10 bed volumes of 1 molar sodium nitrate. Excess sodium nitrate was removed by washing with ten bed volumes of water. After the nitrate and water washing method, the resin was collected by suction filtration and airdried overnight.

\section{RSST Testing}

The RSST was used to characterize the thermal effects of the runaway reactions between solid organic resins and aqueous nitric acid solutions, as described previously.(2)

\section{Experimental Data}

The RSST resin test conditions are described in Table 1, and the RSST profiles are shown in Figures 1-4.

\section{RESULTS AND DISCUSSION}

\section{Results of the RSST Tests}

The primary safety concern with the LTE is potential overpressurization of the resin column by the gases evolved. One option is to pretreat the resin before use(2), while 
Table 1. Replicate Resin Tests Performed in the RSST Calorimeter.

\begin{tabular}{|c|c|c|c|c|c|}
\hline $\begin{array}{c}\text { RSST } \\
\text { Test } \\
\text { Number }\end{array}$ & $\begin{array}{c}\text { Mass } \\
\text { Resin } \\
(\mathrm{g})\end{array}$ & $\begin{array}{c}\text { Mass } \\
8 \mathrm{M} \mathrm{HNO}_{3} \\
(\mathrm{~g})\end{array}$ & $\begin{array}{c}\text { Initiation } \\
\text { Temp } \\
\left({ }^{\circ} \mathrm{C}\right)\end{array}$ & $\begin{array}{c}\text { Maximum } \\
\text { Self-heating Rate } \\
\left({ }^{\circ} \mathrm{C} / \mathrm{min}\right)\end{array}$ & $\begin{array}{c}\text { Maximum } \\
\text { Pressure Rate } \\
(\mathrm{psi} / \mathrm{min})\end{array}$ \\
\hline 115 & 2.86 & 7.38 & 69 & 3.7 & 0.47 \\
\hline 135 & 2.86 & 7.38 & 69 & 0.7 & 0.17 \\
\hline 137 & 2.86 & 7.38 & 69 & 1 & 0.27 \\
\hline 143 & 2.86 & 7.37 & 71 & 1.1 & 0.22 \\
\hline 191 & 2.87 & 7.38 & 67 & 1.2 & 0.25 \\
\hline
\end{tabular}

another option is to use untreated resin and assume the additional risks due to the presence of the LTE. To assess this risk, replicate RSST tests of Reillex ${ }^{\mathrm{TM}}$ HPQ in nitric acid were performed (Fig1-4, Table1). The LTE initiated at an average of $69^{\circ} \mathrm{C}$, with the expected runaway behavior initiating above $100{ }^{\circ} \mathrm{C}$. The LTE reached an average maximum self-heating rate of $2{ }^{\circ} \mathrm{C} / \mathrm{min}$ with a small pressure rate increase of $0.3 \mathrm{psi} / \mathrm{min}$ (average). Before the onset of the LTE, baseline experimental rates of temperature and pressure were $\sim 0.4{ }^{\circ} \mathrm{C} / \mathrm{min}$ and $\sim 0.1 \mathrm{psi} / \mathrm{min}$, respectively. Although the self-heating and pressure rate measurements show large variations, the RSST was sufficiently sensitive to detect this exotherm, and the data were used in a bounding calculation to assess the risk of using untreated resin for processing nuclear materials.

\section{Assumptions Used in the Calculation}

This calculation assumes that a typical process-scale ion exchange column containing 20 liters of untreated resin in $8 \mathrm{M}$ nitric acid is inadvertently heated to $85{ }^{\circ} \mathrm{C}$, activating the low temperature exotherm. Ion exchange column dimensions used in this analysis are identified. The column has an ever-open vent comprised of approximately 
50 feet of $\frac{1}{2} 2$-inch Schedule 18 tubing (ID $=0.402$ inches). Table 2 lists the column dimensions and parameters required to scale volumetric gas rates from the RSST tests to the column.

Table 2. Comparison of Ion Exchange Column Conditions and Dimensions with RSST Test Conditions

\begin{tabular}{|l|c|}
\hline Parameter & Value \\
\hline Column diameter & 7.625 inches \\
\hline Resin bed depth & 27 inches \\
\hline Resin bulk density & $0.6441 \mathrm{~g} / \mathrm{cm}^{3}$ \\
\hline Resin mass, RSST test & $2.87 \mathrm{~g}$ \\
\hline Volumetric scaling factor for gas generation & 4270 \\
\hline Vent line diameter & 0.402 inches \\
\hline Vent line length & 50 feet \\
\hline Vent line fittings & $90^{\circ}$ elbows \\
\hline
\end{tabular}

During normal column operation the vent line is filled with liquid to a level approximately 3 feet above the liquid level in the column. Recently, on the SRS column, a 2-inch vent was added to protect against pressurization by a high temperature excursion. This vent has two 60-psig rupture disks, so it will not provide any relief until the column reaches its tested design pressure of $60 \mathrm{psig}$. (The column was hydrostatically tested at 1.5 times this pressure, or $90 \mathrm{psig}$.) The 2 -inch vent was sized based on the results of the RSST tests and an analysis by Fauske.(3)

The safety analysis for the column does not credit the rupture disks for the low temperature exotherm, so the only vent available for this exotherm is the $1 / 2$-inch everopen vent. The following analysis will determine if this vent provides adequate relief. 


\section{Qualitative Description of the Model}

Because a portion of the vent line initially is filled with liquid (Figure 5A), the analysis treats flow through the vent as a single-phase liquid flow with a volumetric flow rate equal to the gas generation rate, as measured during the RSST tests. This assumption is valid only for the early stages of a postulated exotherm. During such an exotherm, after a portion of the liquid has been vented (Figure 5B), the liquid level in the column drops below the vent line intake, and the vent line drains (Figure 5C). Subsequently, the pressure drop becomes negligible, approaching that for single-gas flow.

The analysis bases the volumetric venting required to initiate drainage of the vent line on measured gas holdups for packed beds. The reasoning is that the gas generated during the exotherm displaces a certain percentage of the liquid within the resin bed out the vent. Tests on packed beds have shown that this gas holdup is independent of the gas flow rate. Consequently, once the gas has displaced a given volume of liquid from the column, the liquid level remains constant and the flow out the column changes from liquid phase to gas phase. Practically, this implies that the liquid surface disengages from the vent intake.

\section{Calculation of Pressure Drop in the Vent Line}

The pressure drop in the vent line is calculated using Equations 1 through 15. This analysis considers only the pressure drop due to flow; it neglects gravitational head. (The head is the total rise of the vent line, which is about 20 feet or 9.5 psig at the assumed liquid density of $1.1 \mathrm{~g} / \mathrm{cm}^{3}$.) 
The flow pressure drop in the vent line is the sum of frictional, fitting, and entrance pressure drops, all defined in terms of velocity heads:

$$
\Delta \mathrm{P}=\left(\frac{4 \mathrm{fL}_{\text {vent }}}{\mathrm{d}_{\text {vent }}}+\mathrm{n}_{\text {elbow }} \mathrm{K}_{\text {elbow }}+\mathrm{K}_{\text {entrance }}\right) \frac{1}{2} \rho_{1} \mathrm{v}^{2}
$$

$\mathrm{K}_{\text {elbow }}$, the pressure loss in an elbow, is 0.75 velocity heads, (4) and $\mathrm{K}_{\text {entrance }}$, the entrance loss, is 0.5 velocity heads,(4) All other terms in the in this expression and the remainder of this section are defined in the Nomenclature.

The Fanning friction factor is the maximum of values for laminar flow or for turbulent flow through a smooth-walled pipe:(4)

$$
\mathrm{f}=\max \left\{\frac{16}{\operatorname{Re}},\left(3.6 \log \left(\frac{\operatorname{Re}}{7}\right)\right)^{2}\right\}
$$

where Re is the Reynolds number for liquid flow, defined by

$$
\operatorname{Re}=\frac{\mathrm{d}_{\mathrm{vent}} \rho_{1} \mathrm{v}}{\mu_{1}}
$$

The velocity is computed by dividing the volumetric rate of gas generation, or the molar gas generation rate divided by the molar gas density, by the vent flow area: 


$$
\mathrm{v}=\frac{1}{\mathrm{~A}_{\mathrm{vent}}} \frac{\mathrm{M}}{\rho_{\mathrm{g}}} \frac{\mathrm{dn}_{\mathrm{ixc}}}{\mathrm{dt}}
$$

where the molar gas density is approximated by the ideal gas law:

$$
\frac{\rho_{g}}{M}=\frac{P}{R_{g} T}
$$

with the pressure equal to one atmosphere and the temperature equal to the estimated exotherm temperature of $85^{\circ} \mathrm{C}$ or $358 \mathrm{~K}$, and

$$
\mathrm{A}_{\mathrm{vent}}=\frac{\pi \mathrm{d}_{\mathrm{vent}}^{2}}{4}
$$

The molar gas generation rate in the ion exchange column equals the generation rate measured in the RSST tests scaled by the ratio of the weight of resin in the column bed, $\mathrm{m}_{\mathrm{r}, \mathrm{ixc}}$, to that used in the RSST tests, $\mathrm{m}_{\mathrm{r}, \mathrm{RSST}}$ :

$$
\frac{\mathrm{dn}_{\mathrm{ixc}}}{\mathrm{dt}}=\frac{\mathrm{m}_{\mathrm{r}, \mathrm{ixc}}}{\mathrm{m}_{\mathrm{r}, \mathrm{RSST}}}\left(\frac{\mathrm{dn}_{\mathrm{RSST}}}{\mathrm{dt}}\right)_{\max }
$$


The subscript "max" on the molar generation rate for the RSST tests, $\frac{\mathrm{dn}_{\mathrm{RSST}}}{\mathrm{dt}}$, indicates that this rate is based on a statistical analysis of the results from several different tests, as discussed later.

Table 1 lists the mass of resin used in the RSST tests. The mass of resin in the column is the product of the resin bulk density and the volume of the resin bed:

$$
\mathrm{m}_{\mathrm{r}, \mathrm{ixc}}=\mathrm{V}_{\mathrm{ixc}} \rho_{\mathrm{r}, \mathrm{b}}
$$

The resin bed volume is given by

$$
\mathrm{V}_{\mathrm{ixc}}=\frac{\pi \mathrm{d}_{\mathrm{ixc}}^{2} \mathrm{~L}_{\mathrm{ixc}}}{4}
$$

The final step in the analysis is the calculation of the appropriate gas generation rate for the RSST tests. Because the LTE occurs at a relatively constant temperature, changes in the measured pressures during the exotherm are approximately proportional to increases in the gas contents of the RSST due to gas generation. Thus,

$$
\frac{\mathrm{dn}_{\text {RSST }}}{\mathrm{dt}}=\mathrm{n}_{\mathrm{RSST}} \frac{1}{\Delta \mathrm{P}_{\text {tot }}} \frac{\mathrm{dP}}{\mathrm{dt}}
$$

Both the net pressure increase during the LTE, $\Delta \mathrm{P}_{\text {tot }}$, and the net rate of increase, $\frac{\mathrm{dP}}{\mathrm{dt}}$, are calculated by subtracting a baseline rate of increase of $0.1 \mathrm{psi} / \mathrm{min}$ from the measured 
pressure drops. This baseline rate represents pressure changes due to heating of the RSST, at a rate of $0.4{ }^{\circ} \mathrm{C} / \mathrm{min}$.

As stated previously, the period of interest for this analysis is the initial portion of the LTE, when the gas in the resin bed displaces liquid out the vent. During the initial stages of the exotherm, the measured pressures for all RSST tests that are analyzed increased at approximately the same normalized rate, as shown in Figures 6 and 7. As Figure 6 illustrates, the upper asymptote to the normalized rate of pressure increase is given by

$$
\frac{1}{\Delta \mathrm{P}_{\text {tot }}} \frac{\mathrm{dP}}{\mathrm{dt}}=\frac{0.1}{60} \frac{\Delta \mathrm{P}}{\Delta \mathrm{P}_{\text {tot }}}
$$

where $\Delta \mathrm{P}$ is the increase in pressure from the start of the exotherm and the time is defined in seconds. The transient for Test 135 does not appear in these figures because the baseline rate of pressure increase for that test was not constant, making it impossible to determine the precise starting time for the exotherm.

For the resin column, $\Delta \mathrm{P}$ and $\Delta \mathrm{P}_{\text {tot }}$ represent the pressure increases that would occur during the initial liquid-phase venting and the entire LTE, respectively, if the column were confined. If one assumes, as described earlier, that changes in pressure are proportional to changes in the amounts of gas generated, then

$$
\frac{\Delta \mathrm{P}}{\Delta \mathrm{P}_{\mathrm{tot}}}=\frac{\mathrm{V}_{\mathrm{ixc}} \varepsilon_{\mathrm{pb}}}{\mathrm{n}_{\mathrm{ixc}}} \frac{\rho_{\mathrm{g}}}{\mathrm{M}}
$$


where $\frac{\mathrm{n}_{\mathrm{ixc}}}{\mathrm{V}_{\mathrm{ixc}}} \frac{\mathrm{M}}{\rho_{\mathrm{g}}}$ is the total number of resin bed volumes of gas generated and $\varepsilon_{\mathrm{pb}}$ is the gas holdup, evaluated as the equilibrium holdup in a packed bed. Tests have shown that for gas flowing through a packed bed of small spheres such as the resin beads the gas holdup approaches 30 volume \%, independent of the gas flow rate.(5) Thus,

$$
\varepsilon_{\mathrm{pb}}=0.3
$$

The amount of gas generation in the column is scaled to the amounts generated in the RSST tests by the resin mass, as described previously for generation rates. This scaling gives

$$
\mathrm{n}_{\mathrm{ixc}}=\frac{\mathrm{m}_{\mathrm{r}, \mathrm{ixc}}}{\mathrm{m}_{\mathrm{r}, \mathrm{RSST}}} \overline{\mathrm{n}}_{\mathrm{RSST}}
$$

Note that this analysis uses a statistically bounding value for the molar rate of gas generation. The bound is a 95\% one-way confidence bound, based on the standard deviation of individually computed generation rates for the five RSST tests. The resulting equation is

$$
\left(\frac{\mathrm{dn}_{\text {RSST }}}{\mathrm{dt}}\right)_{\max }=\frac{\mathrm{dn}_{\text {RSST }}}{\mathrm{dt}}+2.132 \sigma\left\{\frac{\mathrm{dn}_{\mathrm{RSST}}}{\mathrm{dt}}\right\}
$$


Table 3 summarizes the results of the RSST tests and the statistical analysis of the gas generation rates. The last two columns in this table give the equivalent rates of pressure increase and gas generation for the RSST tests during the liquid-phase venting portion of the LTE. These rates are calculated using Equations 10 through 14.

Table 3. Calculation of Maximum Gas Generation for RSST Tests during Initial Venting for Ever-Open Vent Line

\begin{tabular}{|c|c|c|c|c|}
\hline $\begin{array}{c}\text { RSST } \\
\text { Test No. }\end{array}$ & $\begin{array}{c}\Delta \mathbf{P} \\
\text { (psi) }\end{array}$ & $\begin{array}{c}\mathbf{n} \\
(\mathbf{m m o l})\end{array}$ & $\begin{array}{c}\Delta \mathbf{P} / \Delta \mathbf{t} \\
(\mathbf{p s i} / \mathbf{m i n})\end{array}$ & $\begin{array}{c}\Delta \mathbf{n} / \Delta \mathbf{t} \\
(\mathrm{mol} / \mathbf{m i n})\end{array}$ \\
\hline 115 & 4.23 & 3.28 & 0.00985 & $7.65 \mathrm{E}-06$ \\
\hline 135 & 2.56 & 1.99 & 0.00598 & $4.63 \mathrm{E}-06$ \\
\hline 137 & 2.09 & 1.62 & 0.00487 & $3.78 \mathrm{E}-06$ \\
\hline 143 & 1.90 & 1.47 & 0.00443 & $3.43 \mathrm{E}-06$ \\
\hline 191 & 1.80 & 1.40 & 0.00420 & $3.25 \mathrm{E}-06$ \\
\hline Average $=$ & & 1.95 & & 4.55E-06 \\
\hline Standard Deviation $=$ & & & & $1.81 \mathrm{E}-06$ \\
\hline 95\% Confidence Limit $=$ & & & & $8.41 \mathrm{E}-06$ \\
\hline
\end{tabular}

The preceding analysis implicitly assumes that the gas bubbles will disengage from the liquid above the resin bed. A quick calculation of the minimum freeboard height required for disengagement verified that this assumption is valid. The minimum freeboard height, $\mathrm{h}$, is given by(6)

$$
\mathrm{h}=\left(\frac{\dot{\mathrm{Q}}}{2 \pi \mathrm{U}_{\mathrm{E}}}\right)^{1 / 2}
$$


where $U_{E}$ is the Kutateladze entrainment velocity, defined by

$$
\mathrm{U}_{\mathrm{E}}=3\left(\frac{\sigma_{1} \mathrm{~g} \rho_{1}}{\rho_{\mathrm{g}}^{2}}\right)^{1 / 4}
$$

The calculated minimum freeboard height is only about $0.05 \mathrm{~cm}$.

Table 4 lists pertinent results of this calculation. The results of the analysis show that the flow pressure drop for the low temperature exotherm totals about 0.33 psi. This pressure drop is negligible compared to both the rated column and rupture disk pressure of $60 \mathrm{psig}$ and the estimated gravitational head of $9.5 \mathrm{psi}$ that could occur during an exotherm.

Table 4. Summary of Results of Ion Exchange Column Pressure Drop Analysis

\begin{tabular}{|l|r|l|}
\hline Parameter & \multicolumn{2}{|c|}{ Value } \\
\hline Gas Generated during Exotherm & 12.87 & bed volumes \\
\hline Gas Holdup in Column & 0.3 & bed volume \\
\hline Normalized Rate of Pressure Rise & $3.88 \mathrm{E}-05$ & $\mathrm{~L} / \mathrm{s}$ \\
\hline Gas Generation Rate & $6.35 \mathrm{E}-04$ & $\mathrm{~mol} / \mathrm{s}$ \\
\hline Volumetric Flow Rate & 18.7 & $\mathrm{~cm} 3 / \mathrm{s}$ \\
\hline Vent Velocity & 23 & $\mathrm{~cm} / \mathrm{s}$ \\
\hline Flow Pressure Drop & 0.37 & $\mathrm{psi}$ \\
\hline
\end{tabular}

\section{$\underline{\text { SUMMARY }}$}

A pressure drop calculation shows that if a typical process-scale column of Reillex ${ }^{\mathrm{TM}} \mathrm{HPQ}$ inadvertantly reaches $85^{\circ} \mathrm{C}$, the resulting pressurization could be 
dissipated safely via a 0.5 -inch ever-open vent, so that the risk of initiating a runaway reaction with processing actinides with untreated resin is low.

\section{NOMENCLATURE}

Variable:
$\mathrm{A}_{\text {vent }}$
$\mathrm{d}_{\mathrm{ixc}}$
$\mathrm{d}_{\text {vent }}$
f
g
$\mathrm{h}$
$\mathrm{K}_{\text {elbow }}$
$\mathrm{K}_{\text {entrance }}$
$\mathrm{L}_{\mathrm{ixc}}$
$\mathrm{L}_{\text {vent }}$
M
$\mathrm{m}_{\mathrm{r}, \mathrm{RSST}}$
$\mathrm{m}_{\mathrm{r}, \mathrm{ixc}}$
$\mathrm{n}_{\text {RSST }}$
vent line cross-sectional flow area, $\mathrm{cm}^{2}$
ion exchange column diameter, $\mathrm{cm}$
vent line inner diameter, $\mathrm{cm}$
Fanning friction factor, dimensionless
gravitational acceleration, $\mathrm{cm} / \mathrm{sec}^{2}$
minimum freeboard height for disengagement of bubbles from
liquid layer, $\mathrm{cm}$
pressure drop across vent line elbow or $90^{\circ}$ bend, velocity heads
(dimensionless)
vent line entrance pressure drop, velocity heads (dimensionless)
resin bed height, $\mathrm{cm}$
total vent line length, $\mathrm{cm}$
molecular weight, $\mathrm{g} / \mathrm{mol}$
mass of resin used in the RSST tests, $\mathrm{g}$
mass of resin in the column bed, $\mathrm{g}$
number of moles of gas generated during the low temperature

Definition: 
exotherm for an RSST test, dimensionless

$\overline{\mathbf{n}}_{\text {RSST }}$

$\mathrm{n}_{\text {elbow }}$

$\mathrm{n}_{\mathrm{ixc}}$

$\mathrm{P}$

$\Delta \mathrm{P}$

$\Delta \mathrm{P}_{\mathrm{vent}}$

$\Delta \mathrm{P}_{\text {tot }}$

$\dot{Q}$

$\mathrm{R}_{\mathrm{g}}$

$\operatorname{Re}$

$\mathrm{t}$

$\mathrm{T}$

$\mathrm{U}_{\mathrm{E}}$ average number of moles of gas generated during the low

temperature exotherm for all RSST tests, dimensionless

number of elbows or $90^{\circ}$ bends in the vent line, dimensionless

number of moles of gas that would be generated during a low

temperature exotherm in the ion exchange column, dimensionless

pressure, psi

initial pressure increase during an LTE for an RSST test, pressure

increase during the liquid-phase venting portion of an LTE if the

resin column were confined, psi

pressure drop for flow through the vent line during a low

temperature exotherm, psi

total pressure increase during an LTE for an RSST test, total

pressure increase during an LTE if the resin column were confined,

psi

volumetric gas generation rate, $\mathrm{cm}^{3} / \mathrm{sec}$

molar gas constant, $\mathrm{cm}^{3} \mathrm{~atm} / \mathrm{K} / \mathrm{mol}$

Reynolds number for liquid phase flow through vent line,

dimensionless

time, sec

temperature, $\mathrm{K}$

Kutateladze entrainment velocity, used in calculation of minimum 
freeboard height for bubble disengagement, $\mathrm{cm} / \mathrm{sec}$

V

velocity for flow through vent line, $\mathrm{cm} / \mathrm{sec}$

$\mathrm{V}_{\mathrm{ixc}}$

resin bed volume in ion exchange column, $\mathrm{cm}^{3}$

$\varepsilon_{\mathrm{pb}}$

maximum gas phase holdup (volume fraction gas) in a packed bed,

dimensionless

$\mu_{1}$

liquid viscosity, $\mathrm{g} / \mathrm{cm} / \mathrm{sec}$

$\rho_{g}$

gas density, $\mathrm{g} / \mathrm{cm}^{3}$

$\rho_{1}$

liquid density, $\mathrm{g} / \mathrm{cm}^{3}$

$\rho_{\mathrm{r}, \mathrm{b}}$

bulk resin density, $\mathrm{g} / \mathrm{cm}^{3}$

$\sigma_{1}$

liquid surface tension, dyne/cm

$\left(\frac{\mathrm{dn}_{\mathrm{RSST}}}{\mathrm{dt}}\right)_{\max }$

upper bound for molar rate of gas generation during a low

temperature exotherm in the RSST, based on a 95\% confidence

limit, $\mathrm{mol} / \mathrm{sec}$

$\frac{\mathrm{d} \overline{\mathrm{n}}_{\text {RSST }}}{\mathrm{dt}}$

average molar rate of gas generation during the low temperature

exotherms in all five RSST tests, $\mathrm{mol} / \mathrm{sec}$

$\sigma\left\{\frac{\mathrm{dn}_{\mathrm{RSST}}}{\mathrm{dt}}\right\}$

standard deviation for the molar rate of gas generation during the

low temperature exotherms in all five RSST tests, $\mathrm{mol} / \mathrm{sec}$ 


\section{REFERENCES}

1. S.F. Marsh, "Evaluation of a New Macroporous Polyvinylpyridine Resin for Processing Plutonium Using Nitrate Anion Exchange”, report LA-11490, Los Alamos National Laboratory, Los Alamos, New Mexico (April 1989).

2. W.J. Crooks III, E.A. Kyser, S.R. Walter, "Low-temperature Exothermic Reaction of Reillex HPQ in Nitric Acid", submitted for publication.

3. Fauske and Associates, Inc., "Relief Sizing for HB-Line Resin Column," Report WSRC-TR-2001-00064, Westinghouse Savannah River Company, Aiken, South Carolina (February 2001).

4. R.H. Perry and D.W. Green, eds., Perry's Chemical Engineers' Handbook, 6th ed., McGraw-Hill, New York (1984).

5. G.V. Vunjak-Novakovic, D.V. Vukovic, H. Littman, "Hydrodynamics of Turbulent Bed Contactors: 1. Operating Regimes and Liquid Hold-up, 2. Pressure Drop, Bed Expansion, and Minimum Fluidizing Velocity", Ind. Eng. Chem. Res. 26, 958 (1987).

6. H. K. Fauske, "Properly Sized Vents for Nonreactive and Reactive Chemicals," Chem. Eng. Prog., p.17 (February 2000). 


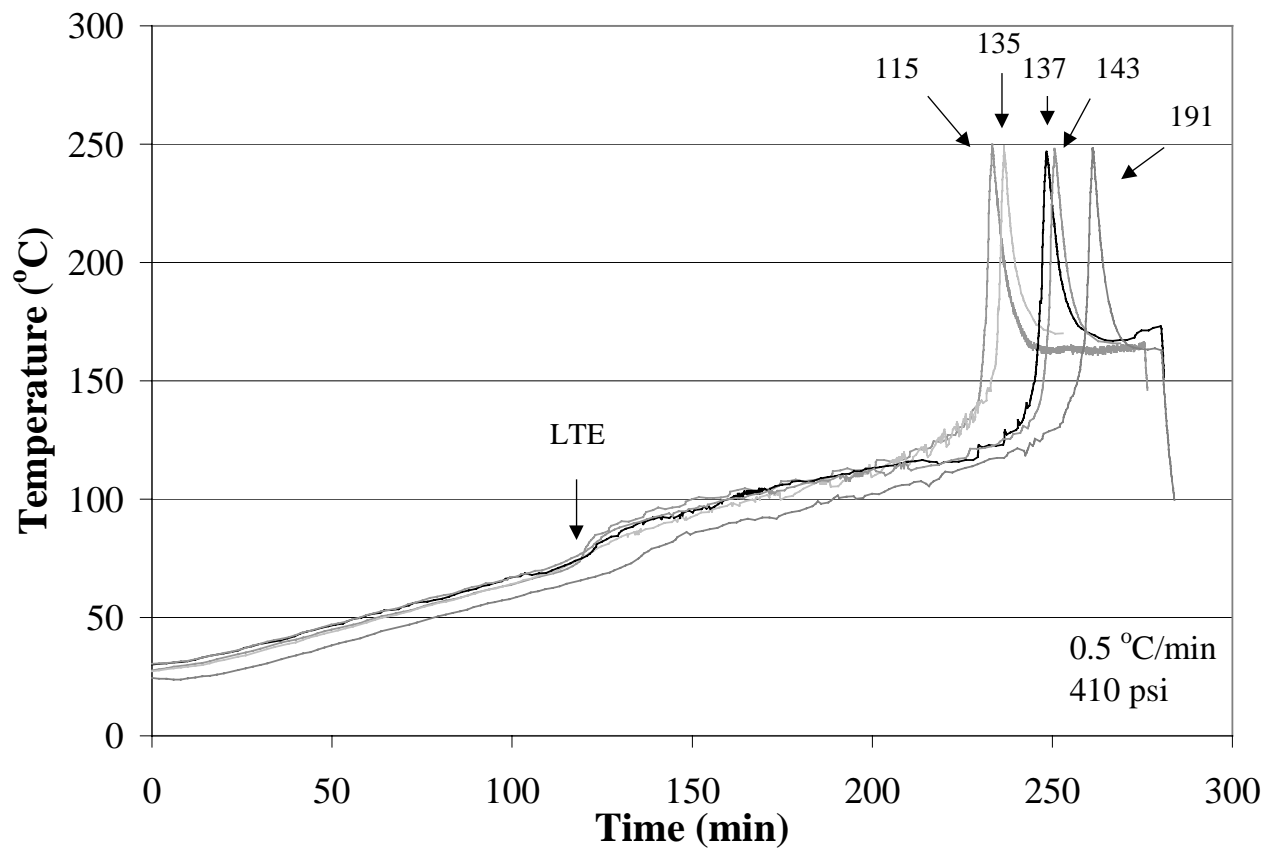

Figure 1. Reillex ${ }^{\mathrm{TM}} \mathrm{HPQ}$ reactions with $8 \mathrm{M}$ nitric acid: Temperature versus Time 


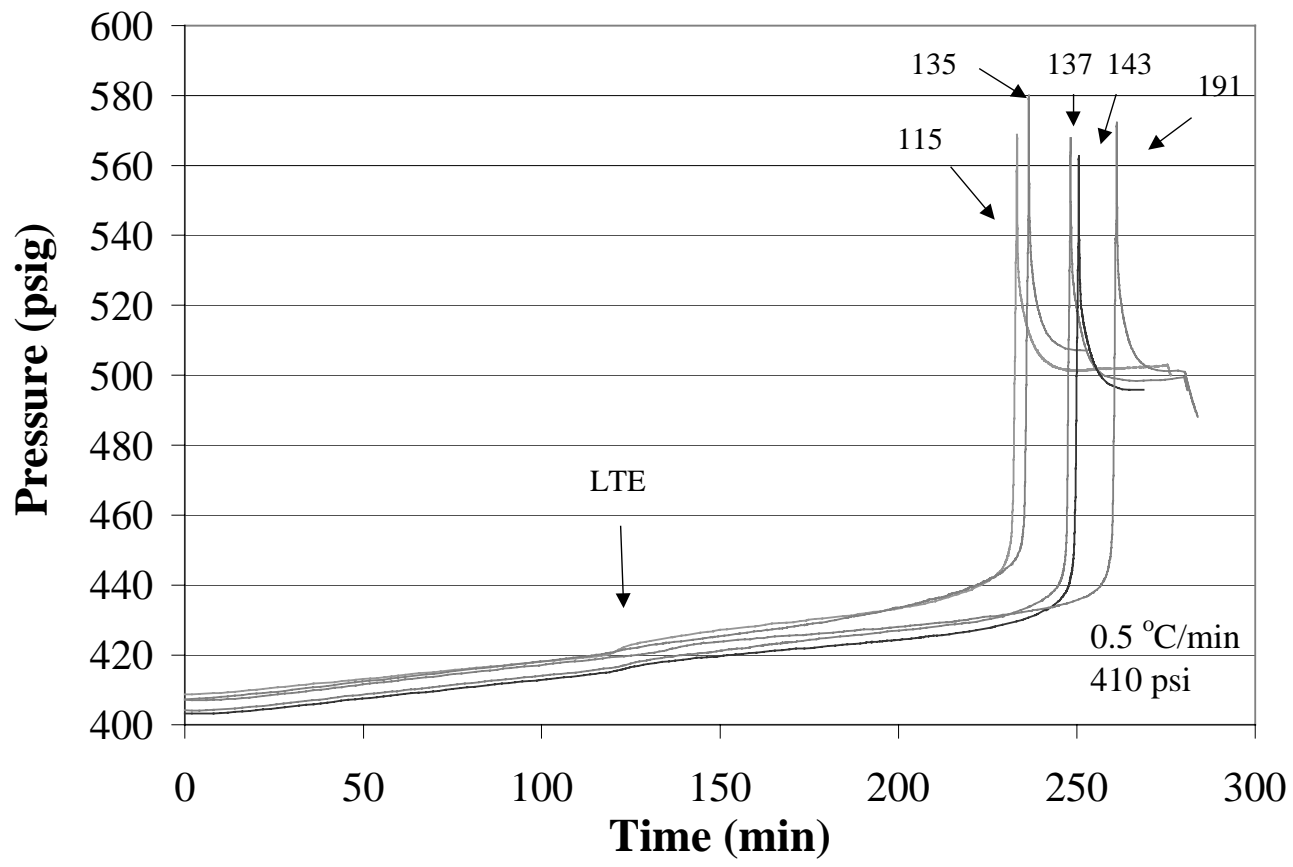

Figure 2. Reillex ${ }^{\mathrm{TM}} \mathrm{HPQ}$ reactions with $8 \mathrm{M}$ nitric acid: Pressure versus Time 


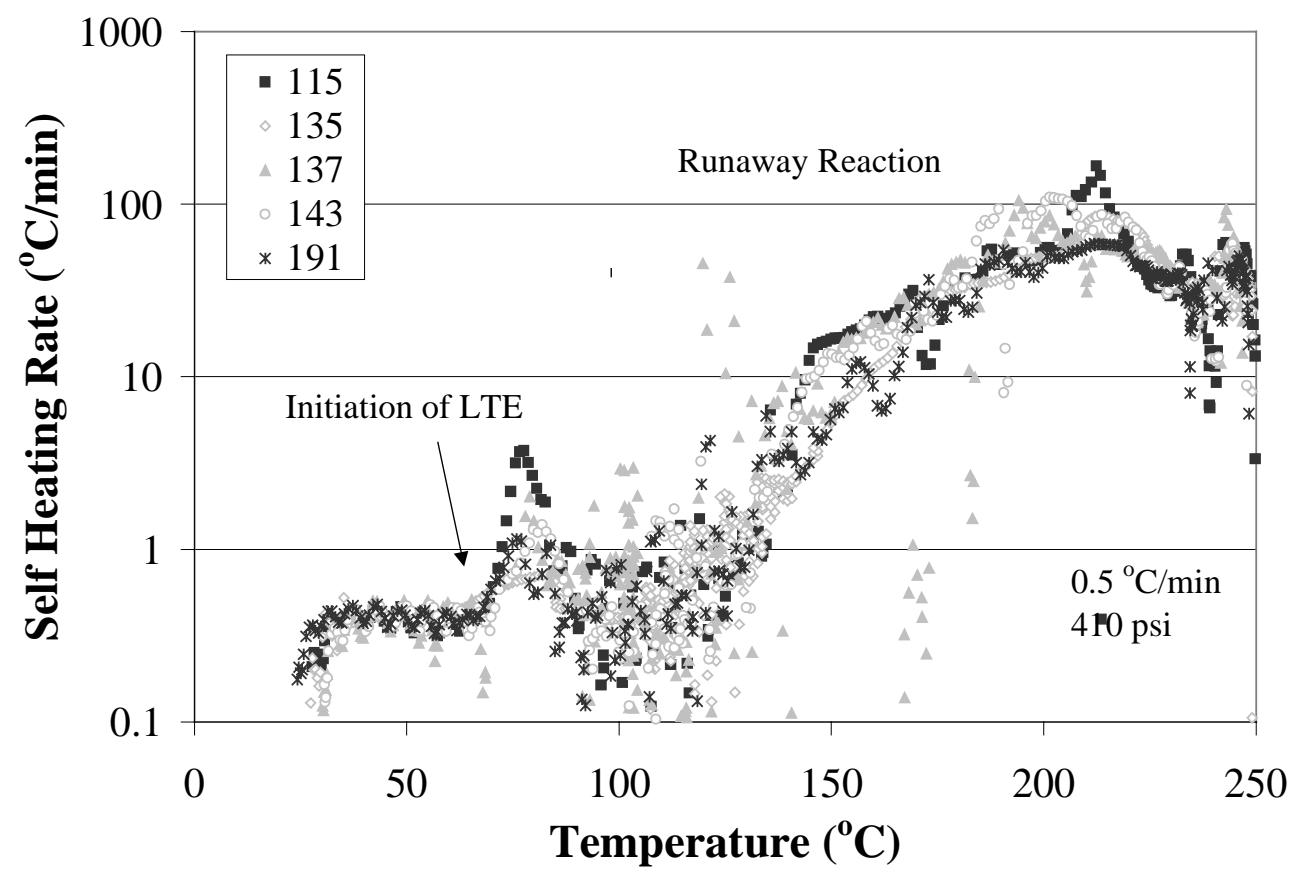

Figure 3. Reillex ${ }^{\mathrm{TM}} \mathrm{HPQ}$ reactions with $8 \mathrm{M}$ nitric acid: Self-heating Rate versus Time 


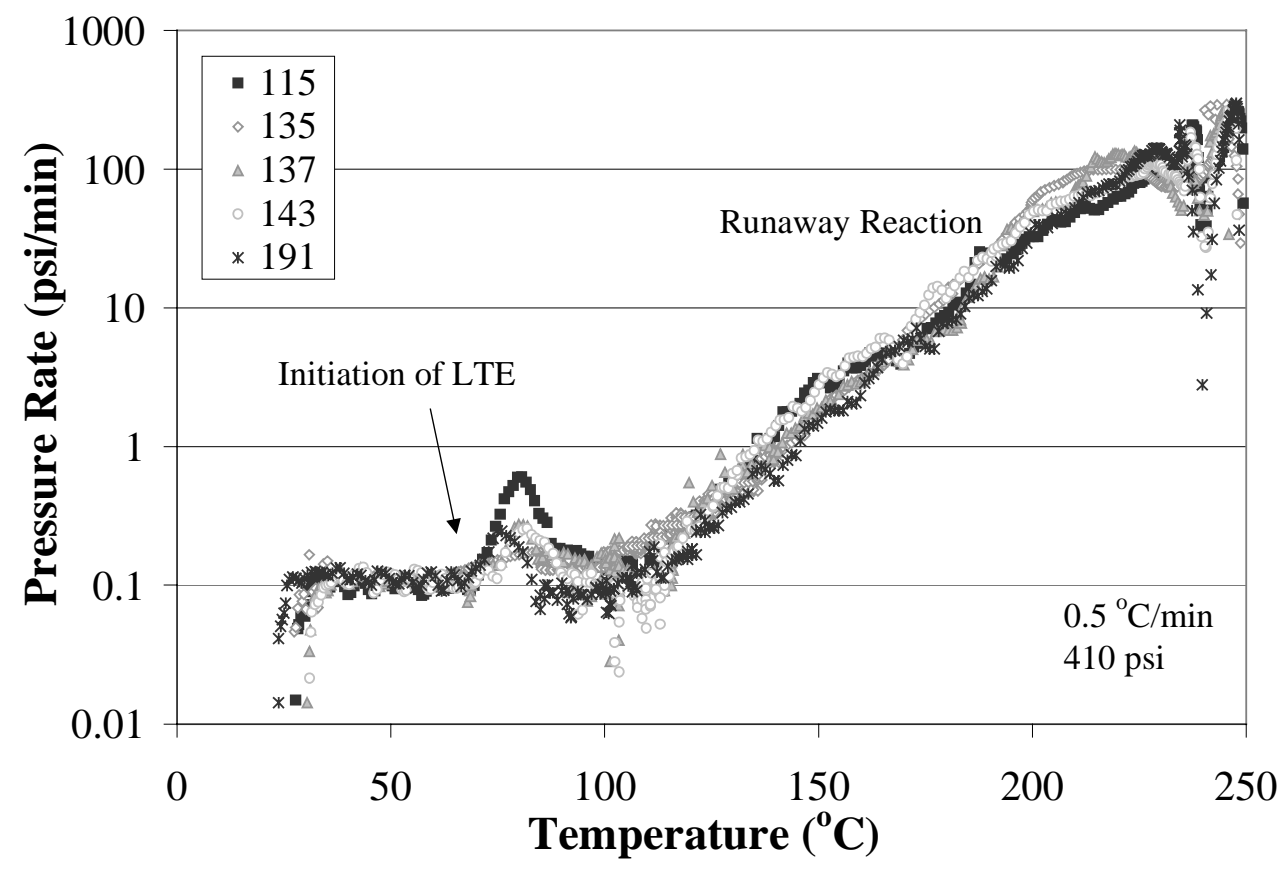

Figure 4. Reillex ${ }^{\mathrm{TM}} \mathrm{HPQ}$ reactions with $8 \mathrm{M}$ nitric acid: Pressure Rate versus Time 


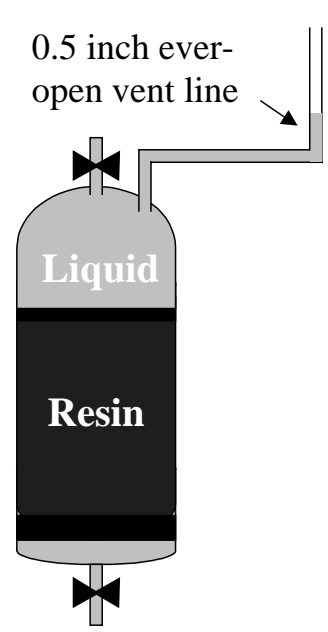

A

Resin bed prior to LTE

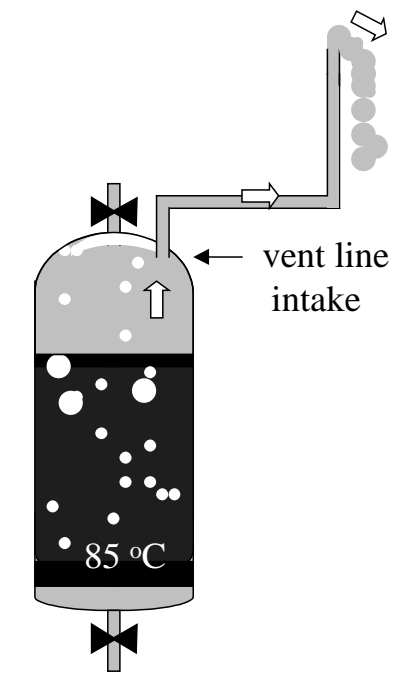

B

Gas displaces liquid from the resin bed.

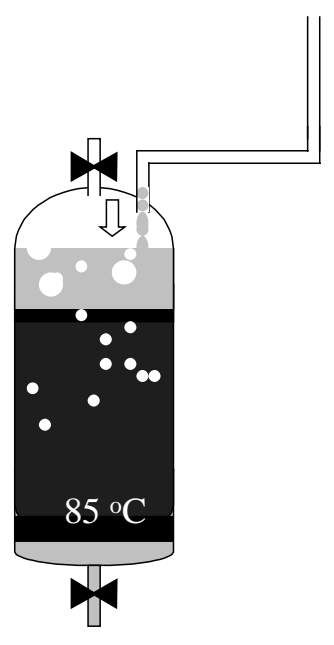

C

Liquid level drops below vent inlet, and vent line drains.

Figure 5. Schematic representing the liquid ejection through the ever-open vent as a result of the LTE (equipment dimensions not to scale) 


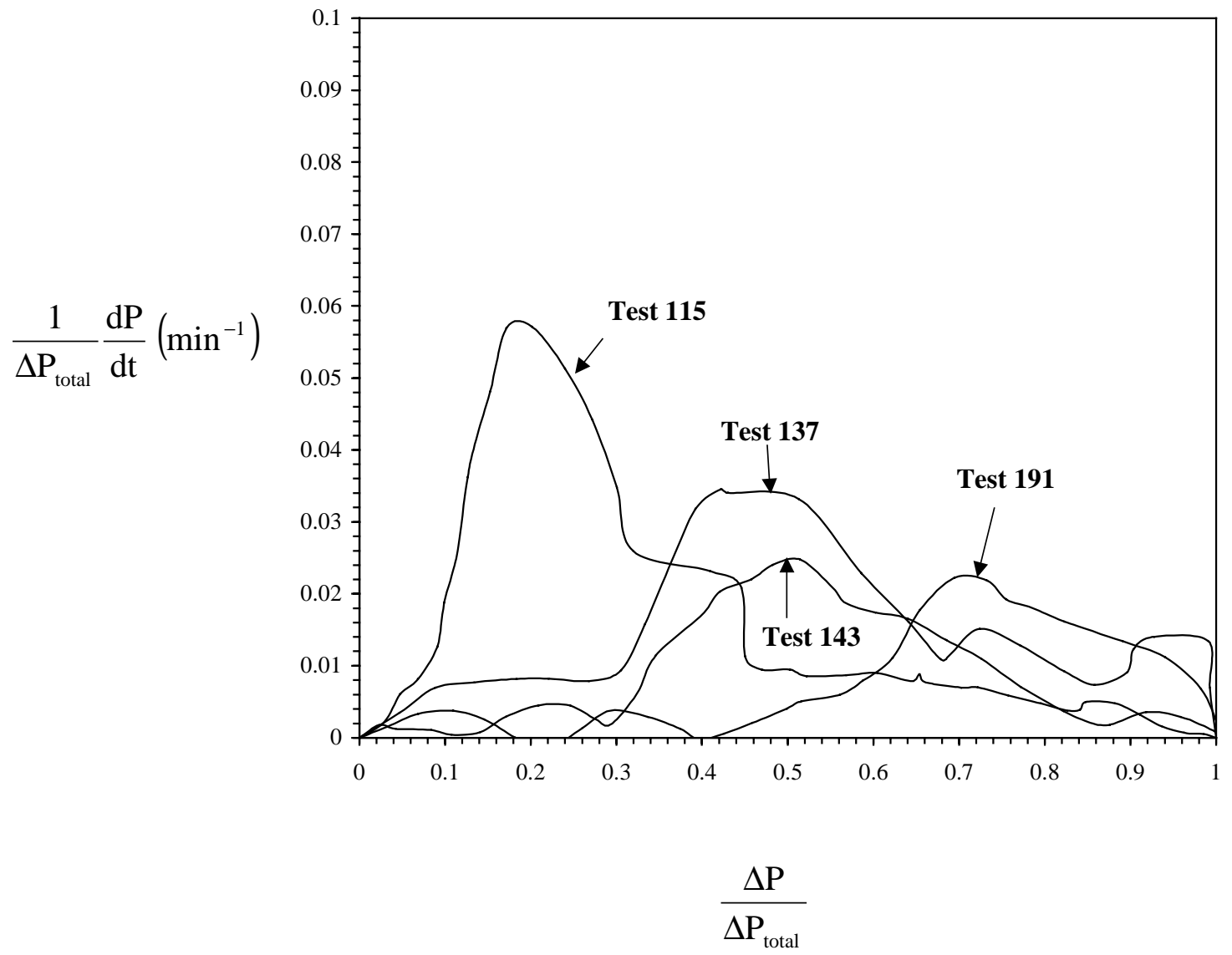

Figure 6. Variation of rate of pressure increase during the LTE 


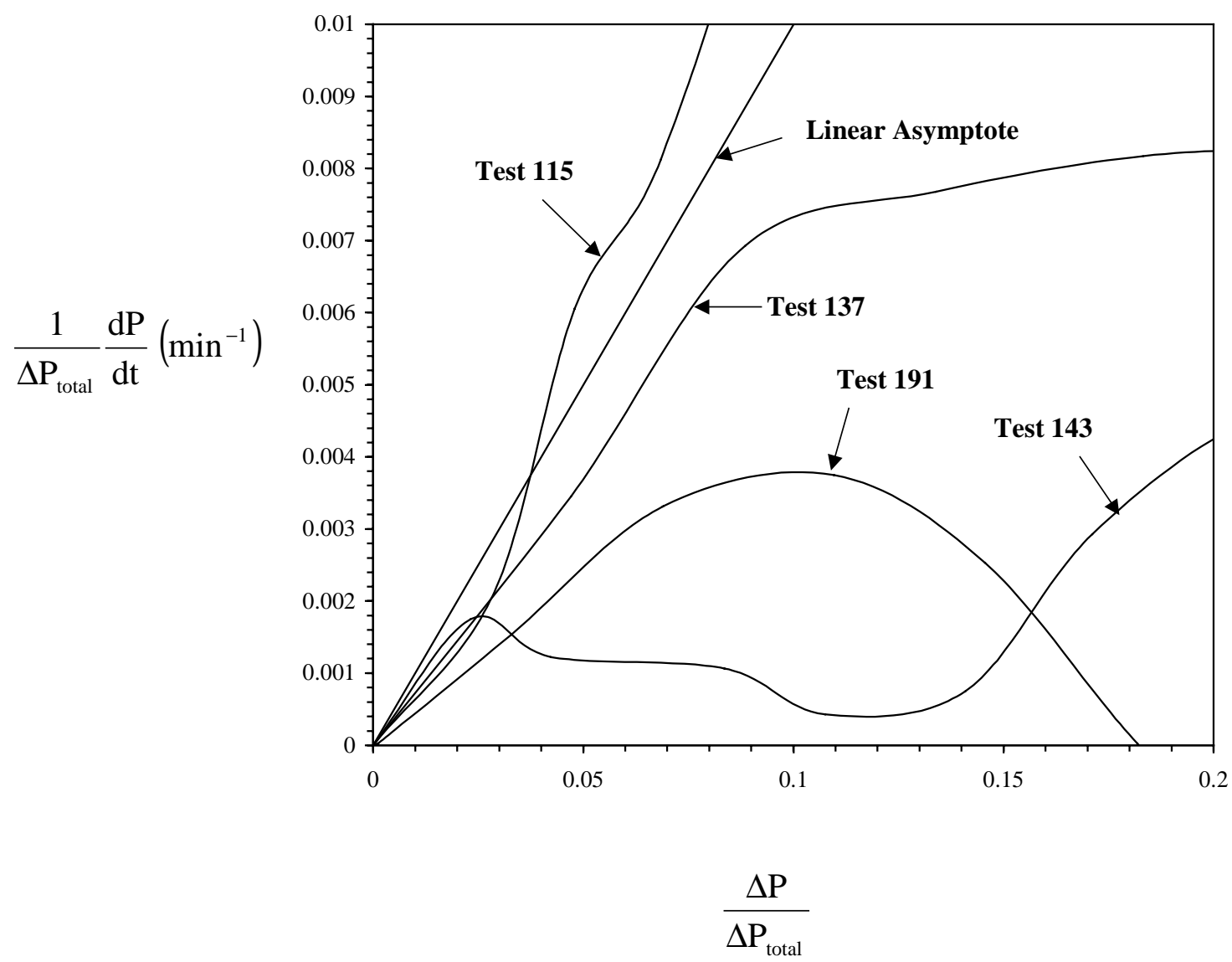

Figure 7. Variation of rate of pressure increase during the LTE, showing asymptotic maximum rate of increase in initial stages of exotherm. 